\title{
In vitro organogenesis and genetic transformation of mandarin cultivars
}

\author{
Leonardo Soriano르 Eveline Carla da Rocha Tavano², Marcelo Favaretto Correa ${ }^{3}$, Ricardo Harakava ${ }^{4}$, \\ Beatriz Madalena Januzzi Mendes ${ }^{5}$, Francisco de Assis Alves Mourão Filho ${ }^{6}$
}

\begin{abstract}
The in vitro organogenesis of Fremont (Citrus clementina $\mathrm{x}$ Citrus reticulata), Thomas (Citrus reticulata), and Nules (Citrus clementina) mandarins was evaluated aiming to optimize a regeneration protocol that could be applied in genetic transformation. The use of epicotyl-derived explants resulted in higher explant responsiveness and number of shoots developed per explant when compared with the use of internodal-derived explants. The highest efficiency in shoot regeneration was observed in the presence of $1 \mathrm{mg} \mathrm{L}^{-1}$ of BAP, regardless of the explant type and cultivar. The in vitro organogenesis protocol produced transgenic plants from three mandarin cultivars expressing attA gene under the control of phloem-specific promoters.

Index Terms: antimicrobial peptide, cultivar improvement, cytokinin, huanglongbing, transgenic plants.

\section{Organogênese in vitro e transformação genética de cultivares de tangerina}

Corresponding author: francisco.mourao@usp.br

Received: September 19, 2018

Accepted: January 04, 2019

Copyright: All the contents of this journal, except where otherwise noted, is licensed under a Creative Commons Attribution License.

\begin{abstract}
Resumo - A organogênese in vitro das tangerinas Fremont (Citrus clementina x Citrus reticulata), Thomas (Citrus reticulata) e Nules (Citrus clementina) foi avaliada visando a otimizar o protocolo de regeneração para aplicação da transformação genética. O uso de explantes derivados de epicótilo resultou em maior número de explantes responsivos e maior número de brotações desenvolvidas por explante, quando comparado ao uso de explantes derivados de segmentos internodais. A maior eficiência na regeneração de brotos foi observada na presença de $1 \mathrm{mg} \mathrm{L}^{-1}$ de BAP, independentemente do tipo de explante e da cultivar. O protocolo de organogênese in vitro produziu plantas transgênicas das três cultivares de tangerina, expressando o gene attA sob o controle de promotores específicos de floema.
\end{abstract}

Termos para indexação: citocinina, huanglongbing, melhoramento de cultivares, peptídeo antimicrobiano, plantas transgênicas. 


\section{Introduction}

In the last three decades, the citrus genetic transformation has been successfully applied to the production of transgenic plants of different citrus species and the introduction of transgenes coding for several characteristics, such as resistance to biotic and abiotic stress (KOBAYASHI; UCHIMYA, 1989; BARBOSAMENDES et al., 2009; CARDOSO et al., 2010). Although genetic transformation can be accomplished by particle bombardment, PEG, and Agrobacterium-mediated, this last method has been the most frequently used in citrus (DONMEZ et al., 2013).

Sweet orange cultivars (BOSCARIOL et al., 2006), Carrizo citrange (DUTT; GROSSER, 2009), and trifoliate hybrids (ZOU et al., 2008) present high genetic transformation efficiency. However, some species, such as sour orange (GUTIÉRREZ et al. 1997; GHORBEL et al., 2000), Rangpur lime (AZEVEDO et al., 2006), and mandarins (CERVERA et al., 2008) are considered recalcitrant to the process. This low genetic transformation efficiency may be influenced by factors related to Agrobacterium inoculation procedure, co-cultivation conditions, and in vitro regeneration efficiency of explants after infection with Agrobacterium (COSTA et al., 2002; RODRIGUEZ et al., 2008; DUTT; GROSSER, 2009; YANG et al., 2016).

In vitro citrus organogenesis is usually induced from juvenile tissue, including epicotyl-derived segments extracted from in vitro germinated seedlings (GARCIALUIS et al., 2006; SORIANO et al., 2012) or internodalderived segments extracted from juvenile plants cultivated under greenhouse conditions (TAVANO et al., 2009; MARQUES et al., 2011). In most of citrus tissue culture protocols, the development of adventitious shoots occurred in culture media supplemented with growth regulators (SILVA et al., 2005; OLIVEIRA et al., 2010; BASSAN et al., 2011). However, the requirements for optimal in vitro regeneration varies according to the genotype (BORDÓN et al., 2000). In experiments involving transformation of mature tissue of sweet orange (C. sinensis), the use of 3 $\mathrm{mg} \mathrm{L}^{-1}$ of 6-benzylaminopurine (BAP) in the regeneration medium induced an opposite effect in in vitro responses, leading to efficient shoot organogenesis in Pineapple, but not in the cultivar Navelina (RODRIGUEZ et al., 2008). Considering these aspects, the in vitro organogenesis from closely related mandarin cultivars was studied to adjust the regeneration protocol and to use it for Agrobacteriummediated genetic transformation.

The mandarin cultivars Thomas (Citrus reticulata) and Nules (Citrus clementina) and the intraspecific hybrid Fremont (Citrus clementina x Citrus reticulata) have great potential to be used in mandarin commercial production (PIO et al., 2006). However, these cultivars are affected by Huanglongbing (HLB). Currently, HLB is considered as the main citrus disease, associated with the bacteria Candidatus Liberibacter spp., which colonize phloem tissues (BOVÉ, 2006). Genetic engineering may be an alternative to HLB management. The expression of genes coding for antimicrobial peptides at the pathogen colonization site may be a good strategy to restrict the bacterial multiplication in infected plants. The expression of the attA gene, which codes for the antimicrobial peptide attacin A, showed to be effective in reducing $C$. sinensis susceptibility to Xanthomonas citri subsp. citri (BOSCARIOL et al., 2006; CARDOSO et al., 2010). The production of transgenic mandarin plants expressing the att A gene in the phloem tissue seems to be an adequate approach to manage HLB disease.

This study investigated the in vitro organogenesis of epicotyl and internodal-derived segments from Fremont, Thomas, and Nules mandarins. The protocol was then used to produce transgenic plants expressing the attA gene under the control of Arabidopsis thaliana sucrose transporter 2 promoter (AtSuc2) or A. thaliana phloem protein 2 (AtPP2) promoter, in an attempt to express the attA gene preferentially at the phloem tissue, aiming to reduce the susceptibility to $C a$. Liberibacter spp.

\section{Materials and Methods}

\section{Plant Material}

Seeds were extracted from mature fruits of the mandarin cultivars Fremont (Citrus clementina x Citrus reticulata), Thomas (Citrus reticulata), and Nules (Citrus clementina). The seed coat was removed, and seeds were treated with sodium hypochlorite solution $(0.5 \%$ active chloride; $20 \mathrm{~min}$ ) for asepsis, followed by three rinses with sterile water. For in vitro germination, seeds were transferred to test tubes containing MS salts and vitamins solid culture medium (MURASHIGE; SKOOG, 1962), incubated at $27^{\circ} \mathrm{C}$, in the dark ( 3 - 4 weeks), and transferred to a $16-\mathrm{h}$ photoperiod $(10 \mathrm{~d})$. Epicotyl segments $(0.8-1.0 \mathrm{~cm})$ were extracted from in vitro germinated seedlings. Internodal segments $(1 \mathrm{~cm})$ were obtained from new elongated shoots from juvenile mandarin plants cultivated in a greenhouse. Stem pieces were collected, leaves were removed, and explants were disinfected with sodium hypochlorite solution ( $2.5 \%$ active chloride; 20 $\mathrm{min}$ ), followed by three rinses with sterile distilled water.

\section{In vitro organogenesis}

Epicotyl and internodal-derived segments were horizontally cultivated in Petri dish $(100 \times 15 \mathrm{~mm})$ containing MT salts and vitamins solid culture media (MURASHIGE; TUCKER, 1969), supplemented with BAP $\left(0,0.5,1.0,1.5,2.0 \mathrm{mg} \mathrm{L}^{-1}\right)$. The explants were incubated in the dark, at $27^{\circ} \mathrm{C}$, for $30 \mathrm{~d}$, and then transferred to a 16 -h photoperiod $\left(65 \mu \mathrm{mol} \mathrm{m}^{-2} \mathrm{~s}^{-1}\right)$. The evaluation was 
performed at $15 \mathrm{~d}$ after incubation, in a $16-\mathrm{h}$ photoperiod, by determining the percentage of responsive explants and the number of shoots per explant for each treatment. The experimental design was completely randomized, with six replications per treatment. Each replication consisted of six explants, totaling 36 explants per treatment. Three independent experiments were performed for each cultivar. Data were analyzed by ANOVA, and the means were compared by the Tukey's test $(P<0.05)$. The influence of BAP concentrations on in vitro organogenesis was analyzed by regression analysis.

\section{Genetic transformation}

The experiments were performed with pCAtSuc2/ att $\mathrm{A}$ and $\mathrm{pCAtPP} 2 /$ att $\mathrm{A}$ gene constructs, which contain the attA gene under the control of Arabidopsis thaliana sucrose transporter 2 (AtSuc2) or A. thaliana phloem protein 2 (AtPP2) promoters, respectively. Gene constructs were assembled into a pCAMBIA2201 vector and transferred to Agrobacterium tumefaciens, as reported by Tavano et al. (2015). The nptII gene, which confers resistance to the kanamycin antibiotic, was used as a selection gene.

Genetic transformation experiments were performed with epicotyl-derived explants from the mandarin cultivars Fremont, Thomas, and Nules, via A. tumefaciens. The co-culture medium consisted of MT salts and vitamins medium supplemented with BAP $\left(1 \mathrm{mg} \mathrm{L}^{-1}\right)$, acetosyringone $(100 \mathrm{mM})$, sucrose $\left(25 \mathrm{~g} \mathrm{~L}^{-1}\right)$, ascorbic acid $(50 \mathrm{mg}$ $\left.\mathrm{L}^{-1}\right)$, and agar $\left(8 \mathrm{~g} \mathrm{~L}^{-1}\right)$, and the $\mathrm{pH}$ was adjusted to 5.5 . During the co-culture period, the material was incubated in the dark $\left(2 \mathrm{~d} ; 24{ }^{\circ} \mathrm{C}\right)$. This protocol was used based on the results of the protocol adjustment in the first part of this study, where the best explant type and optimum BAP concentration were determined. After this period, the material was transferred to selection and regeneration medium, consisting of MT salts and vitamins medium supplemented with BAP $\left(1 \mathrm{mg} \mathrm{L}^{-1}\right)$, sucrose $\left(25 \mathrm{~g} \mathrm{~L}^{-1}\right)$, ascorbic acid $\left(50 \mathrm{mg} \mathrm{L}^{-1}\right)$, agar $\left(8 \mathrm{~g} \mathrm{~L}^{\mathrm{L}-1}\right)$, cefotaxime (100 $\left.\mathrm{mg} \mathrm{L}^{-1}\right)$, and kanamycin $\left(100 \mathrm{mg} \mathrm{L}^{-1}\right)$, and the $\mathrm{pH}$ was adjusted to 5.8 . The culture was incubated at $27^{\circ} \mathrm{C}$, in the dark, for $30 \mathrm{~d}$, and then transferred to a 16 -h photoperiod. Shoots were in vitro-grafted onto in vitro-germinated Carrizo citrange ( $C$. sinensis x Poncirus trifoliata) seedlings. This procedure has shown to improve the transgenic shoot development since the initial in vitro rooting of transgenic Citrus material is poor, and its further development may be hindered, even after plant acclimation. The putative transgenic plants were identified by PCR analyses. The DNA was extracted from leaves of acclimatized plants by the CTAB method (DOYLE; DOYLE, 1990). PCR analyses were performed to amplify the attA gene, using the primers Att-Psc2-F 5'ACATGTCCCGTTATTTGGTCTTTGAA3' and Att-Bst-R 5'GGTCACCTACCACTTATTACCAAAAGAC3', following the program: $94{ }^{\circ} \mathrm{C}$ for $3 \mathrm{~min} ; 35$ times at $94^{\circ} \mathrm{C}$ for $30 \mathrm{~s} ; 52^{\circ} \mathrm{C}$ for $30 \mathrm{~s} ; 72$
${ }^{\circ} \mathrm{C}$ for $1 \mathrm{~min}$; and a final extension at $72{ }^{\circ} \mathrm{C}$ for $4 \mathrm{~min}$. The transformation efficiency was expressed as the percentage of PCR-positive plants in relation to the total explants inoculated with A. tumefaciens.

\section{Southern blot analysis}

DNA was extracted from leaves of PCR-positive acclimatized plants, using the CTAB method (DOYLE; DOYLE, 1990). DNA $(20-60 \mu \mathrm{g})$ was digested with BamHI (pCAtSuc2/attA) or HindIII (pCAtPP2/attA) restrictions enzymes $\left(5 \mathrm{U} \mathrm{\mu g}^{-1} ; 16 \mathrm{~h}\right)$. BamHI- or HindIIIdigested DNA-fragment were separated by electrophoresis on agarose gel (1\%), transferred to nylon membrane (Hybond $\mathrm{N}^{+}$- GE Healthcare, Little Chalfont, UK), and fixed $\left(80^{\circ} \mathrm{C} ; 2 \mathrm{~h}\right)$. A PCR amplified fragment of the attA gene (150 ng) was labeled with alkaline phosphatase, using AlkaPhos direct labeling reagents (GE Healthcare, Little Chalfont, UK), and used as a probe. Hybridization, washing, and detection were performed by the Gene images CDP star detection kit (GE Healthcare, Little Chalfont, UK), following the manufacturer's instructions.

\section{attA gene transcription analyses}

RNA was extracted from midrib leaves collected from plants identified as Southern blot-positive, using the TRIZOL reagent (Invitrogen, Carlsbad, USA). Isolated RNA was purified (RNAeasy plant mini kit - Qiagen, Hilden, Germany) and treated with DNAse (RNasefree DNase set - Qiagen). The first strand of cDNA was synthesized from DNAse-treated RNA $(1 \mu \mathrm{g})$, using1 $\mu \mathrm{l}$ oligo (dT) $(10 \mu \mathrm{M})$ and $1 \mu 1 \mathrm{M}$-MLV reverse-transcriptase enzyme (Invitrogen, Carlsbad, USA), as described by the manufacturer. RT-qPCR analyses were performed with the 7500 FAST $^{\mathrm{TM}}$ Real-time PCR System (Applied Biosystems, Foster City, USA). The attA gene was amplified with the primers 5'TCGTCACCAAGAACATGCCTGACT3' and 5'AAGAATGGAGTGTTTGCCATGCCG3'. The ubiquitin (UBQ) gene was used to normalize the attA gene transcription. Primers 5'TTCGTCAGTTGACTAATCCT3' and 5'GTTGCTGTGTTGACTGTG3' were used to amplify the UBQ gene (BOAVA et al., 2011). Reactions contained $10 \mu \mathrm{l}$ cDNA ( $25 \mathrm{ng}), 0.6 \mu 1$ primer $(5 \mu \mathrm{M}), 7.5 \mu 1$ Fast Sybr green master mix (Applied Biosystems, Foster City, USA), and $1.9 \mu 1$ RNase-free water. The following program was used: $95^{\circ} \mathrm{C}$ for $20 \mathrm{~s} ; 40$ cycles at $95^{\circ} \mathrm{C}$ for $3 \mathrm{~s}$; and $60^{\circ} \mathrm{C}$ for $30 \mathrm{~s}$; followed by $95^{\circ} \mathrm{C}$ for $15 \mathrm{~s}$. A constant increase in the temperature between 60 ${ }^{\circ} \mathrm{C}$ and $95{ }^{\circ} \mathrm{C}$ was applied during the melting analyses. Two technical replications were used for each cultivar and gene construct. A non-transgenic plant and non-template sample (water) were used as negative controls. Data were analyzed by the LinRegPCR software (RAMAKERS et al., 2003), for primer efficiency calculation, and the REST 2009 software (PFAFFL et al., 2002), for relative quantification of the attA gene transcript, using the comparative 
Ct method $(\Delta \Delta \mathrm{Ct})$. Relative transcription of the attA gene was calculated in relation to the transgenic plant presenting the lowest attA transcript level.

\section{Results and Discussion}

\section{In vitro organogenesis}

In vitro organogenesis was observed in both explant types studied, i.e., the epicotyl and internodal-derived segments from the three mandarin cultivars. Shoot development was registered as early as six weeks after culture, regardless of the culture medium supplementation with BAP (Table 1; Figure 1). In all cultivars, epicotyl segments led to a higher $\%$ of responsive explants and number of shoots per explant (Table 1).

The results for the culture medium supplementation with cytokinin showed that, although BAP is not essential for in vitro organogenesis, the efficiency of shoot development increased up to the concentration of $1 \mathrm{mg} \mathrm{L}^{-1}$, regardless of the cultivar (Table 1; Figure 1). Considering epicotyl-derived explants, the percentages of responsive explants varied from 73.15 to 82.41 in the mandarin cultivars studied, at $1 \mathrm{mg} \mathrm{L}^{-1} \mathrm{BAP}$ concentration. When internodal-derived explants were used, this variable ranged from 40.74 to $54.63 \%$, at the same cytokinin concentration. Similar results were obtained for the variable number of shoots developed per explant, whose maximum values for both explants and the three cultivars studied were obtained with BAP at $1 \mathrm{mg} \mathrm{L}^{-1}$.

The success of genetic transformation programs depends on an efficient in vitro plant regeneration protocol. Considering citrus, epicotyl-derived explants are the most frequently used for genetic engineering in different cultivars (ALMEIDA et al., 2002; SILVA et al., 2005; GARCÍA-LUIS et al., 2006; NWE et al., 2014). Other explants, such as leaf discs- (KHAN et al., 2009), hypocotyl- (MAGGON; SINGH, 1995), cotyledon(TAVANO et al., 2009), and internodal- (MARQUES et al., 2011) derived segments have also been tested; however, they presented lower efficiency. In this study, the adventitious shoot development occurred more frequently from epicotyl-derived explants, with more than $50 \%$ of responsive explants and more than four shoots developed per responsive explant (Table 1), regardless of the cultivar. Similar results have been reported for Volkamer lemon, sour orange, and Rangpur lime species, showing a higher number of responsive explants when epicotylderived explants were used, comparing with internodal or hypocotyl-derived explants (TAVANO et al., 2009; SORIANO et al., 2012).

Considering the regeneration efficiency from epicotyl-derived explants in other citrus species, some of them stand out with high regeneration efficiency, such as Troyer citrange, with 82 to $94 \%$ of responsive explants, and sweet oranges (Natal, Valencia, and Hamlin cultivars), with 71.42 to $85 \%$ of responsive explants (BORDÓN et al., 2000; MOREIRA-DIAS et al., 2001; ALMEIDA et al., 2002). The species considered as less responsive to in vitro organogenesis are Honey $(C$. tangerine $)$ and Cleopatra $(C$. reshni) mandarins, with regeneration efficiency varying from 50 to $62.2 \%$, respectively (SILVA et al., 2005; NWE et al., 2014). Some species, such as sour orange and Rangpur lime, are considered as recalcitrant to in vitro organogenesis, producing less than $50 \%$ of responsive explants (BORDÓN et al., 2000; ALMEIDA et al., 2002). In the present work, the cultivation of epicotyl-derived explants of Fremont, Thomas, and Nules cultivars in culture medium supplemented with $1 \mathrm{mg} \mathrm{L}^{-1}$ of BAP led to regeneration frequencies higher than $70 \%$ (Table 1; Figure $1)$. This result is similar to the regeneration efficiency reported in other studies involving three sweet orange cultivars (C. sinensis) (ALMEIDA et al., 2002) and seems to be adequate for genetic transformation experiments.

\section{Genetic transformation}

The genetic transformation was performed successfully resulting in transgenic plants of Fremont, Thomas, and Nules cultivars harboring the T-DNA that contains the attA gene under the control of AtSuc2 or AtPP2 promoters.

For Fremont, approximately 3200 explants were inoculated with $A$. tumefaciens carrying pCAtPP2/attA or $\mathrm{pCAtSuc2/attA} \mathrm{gene} \mathrm{constructs,} \mathrm{resulting} \mathrm{in} \mathrm{the} \mathrm{production}$ of three and eight transgenic plants, which was confirmed by the PCR analysis, for each construct, respectively (Table 2). For Thomas, about 3000 explants were inoculated with the A.tumefaciens, leading to the regeneration and confirmation of ten and 12 plants of pCAtPP2/attA and pCAtSuc2/attA gene constructs, respectively. Finally, for Nules, about 1600 explants were inoculated with $A$. tumefaciens carrying pCAtPP2/attA or pCAtSuc2/attA gene constructs, resulting in the production of three and two PCR-positive for each construct, respectively (Table 2). The genetic transformation efficiency ranged from $0.22 \%$ to $0.93 \%$. The highest value was obtained for the experiments performed with Thomas cultivar and pCAtSuc2/attA gene construct (Table 2).

Genetic transformation is influenced by transgenic shoot regeneration efficiency after infection with $A$. tumefaciens. Some species are highly responsive to the in vitro organogenesis and genetic transformation, while others are less responsive or even recalcitrant to these processes. The genetic transformation efficiency reported for responsive genotypes, such as the sweet orange cv. Hamlin and Carrizo citrange, ranged from 14 to $47 \%$, respectively (BOSCARIOL et al., 2006; DUTT; GROSSER, 2009). For recalcitrant species, such as Rangpur lime and sour orange, genetic transformation 
efficiency was lower than 2.5\% (GUTIÉRREZ et al., 1997; AZEVEDO et al., 2006).

In the present experiments, although the in vitro organogenesis frequency was higher than $70 \%$, the genetic transformation efficiency obtained for Fremont, Thomas, and Nules mandarins was lower than $1 \%$. This value is lower than the efficiency reported for other mandarin cultivars (KHAWALE et al., 2006; BACHCHU et al., 2011). Besides genotype dependence and regeneration frequency, the genetic transformation efficiency is influenced by other factors, including the Agrobacterium strain and density and the co-cultivation procedure (DUTT; GROSSER, 2009; YANG et al., 2016). The genetic transformation efficiency may also be influenced by gene constructs. A low genetic transformation efficiency was also observed for sweet orange cultivars and gene constructs containing the uidA gene under the control of AtSuc2, AtPP2, or CsPP2 phloem-specific promoters (MIYATA et al., 2012), reinforcing the idea that the gene construct may play an important role in the efficiency of genetic transformation. Future experiments, aiming to increase transformation efficiency, could include other transformation methods such as those evaluated by Dutt et al. (2018) in 'W Murcott' tangor.

The integration and transcription of the attA gene were confirmed by the Southern blot and RT-qPCR analyses, respectively. A total of 32 Southern blot positive plants were confirmed for the three mandarin cultivars and the two gene constructs studied. The T-DNA was inserted in different positions into the plant's genome. Most of the plants had one insertion event; however, two, three, or more than three integration events were also observed (Figure 2). Non-hybridization signal was detected in the non-transgenic plant (control). The transcription of the attA gene was confirmed in representative events from each gene construct for Fremont, Thomas, and Nules cultivars (Figure 3). Most of the transgenic plants showed a high level of the attA gene transcription, ranging from $10^{1}$ to $10^{4}$, in relation to the transgenic plants used as calibrator (Figure 3). The mandarin transgenic plants expressing the attA gene will be challenged with Candidatus Liberibacter spp. to investigate whether the expression of this antimicrobial gene will contribute to enhancing the resistance to HLB disease.

Table 1. In vitro organogenesis from epicotyl and internodal-derived segments from Fremont, Thomas, and Nules mandarins (mean of three experiments, totaling 108 explants per treatment).

\begin{tabular}{|c|c|c|c|c|c|}
\hline \multirow{2}{*}{ cultivars } & \multirow{2}{*}{$\begin{array}{c}\text { BAP (mg } \\
\left.\mathrm{L}^{-1}\right)\end{array}$} & \multicolumn{2}{|c|}{ responsive explants $(\%)$} & \multicolumn{2}{|c|}{ number of shoots/explant } \\
\hline & & epicotyl & internodal & epicotyl & internodal \\
\hline \multirow[t]{5}{*}{ Fremont } & 0.0 & 36.11 & 9.26 & 3.06 & 1.11 \\
\hline & 0.5 & 56.48 & 23.15 & 4.61 & 2.17 \\
\hline & 1.0 & 78.70 & 50.93 & 6.11 & 4.00 \\
\hline & 1.5 & 57.41 & 15.74 & 4.56 & 1.78 \\
\hline & 2.0 & 32.41 & 7.41 & 2.89 & 0.83 \\
\hline mean & & $52.22 \mathrm{~A}$ & $21.30 \mathrm{a}$ & $4.24 \mathrm{~A}$ & $1.98 \mathrm{~b}$ \\
\hline SD & & 18.73 & 17.68 & 1.32 & 1.25 \\
\hline \multirow[t]{5}{*}{ Thomas } & 0.0 & 34.26 & 7.41 & 3.28 & 1.39 \\
\hline & 0.5 & 65.74 & 13.89 & 5.67 & 1.56 \\
\hline & 1.0 & 73.15 & 40.74 & 5.89 & 3.89 \\
\hline & 1.5 & 55.56 & 12.04 & 4.67 & 1.44 \\
\hline & 2.0 & 36.11 & 5.56 & 3.39 & 0.72 \\
\hline mean & & $52.96 \mathrm{~A}$ & $15.93 b$ & $4.58 \mathrm{~A}$ & $1.80 \mathrm{~b}$ \\
\hline SD & & 17.40 & 14.27 & 1.23 & 1.21 \\
\hline \multirow[t]{5}{*}{ Nules } & 0.0 & 30.56 & 16.67 & 3.22 & 2.06 \\
\hline & 0.5 & 54.63 & 24.07 & 5.00 & 2.50 \\
\hline & 1.0 & 82.41 & 54.63 & 6.56 & 5.17 \\
\hline & 1.5 & 54.63 & 18.52 & 4.67 & 2.11 \\
\hline & 2.0 & 31.48 & 12.96 & 3.17 & 1.83 \\
\hline mean & & $50.74 \mathrm{~A}$ & $25.37 \mathrm{a}$ & $4.52 \mathrm{~A}$ & $2.73 a$ \\
\hline SD & & 21.28 & 16.84 & 1.41 & 1.38 \\
\hline
\end{tabular}

Means followed by the same letter in the column are not significantly different by the Tukey's test $(P \leq 0.05)$. 


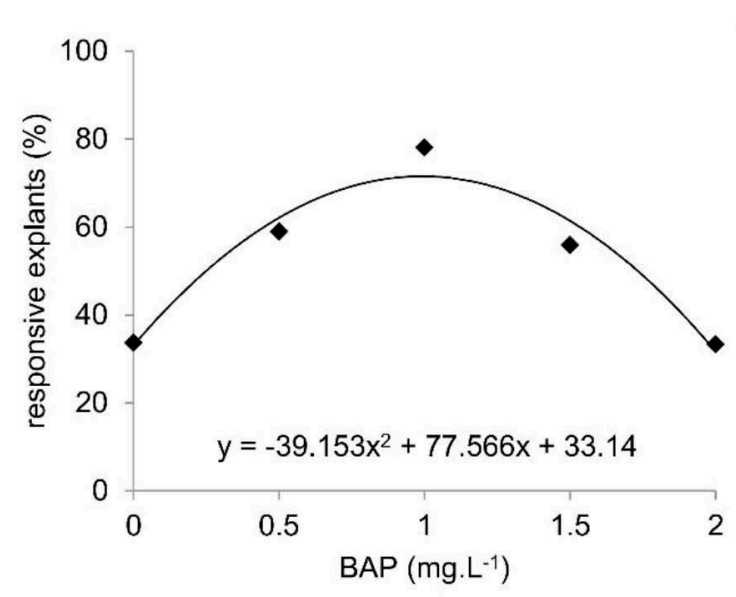

a)

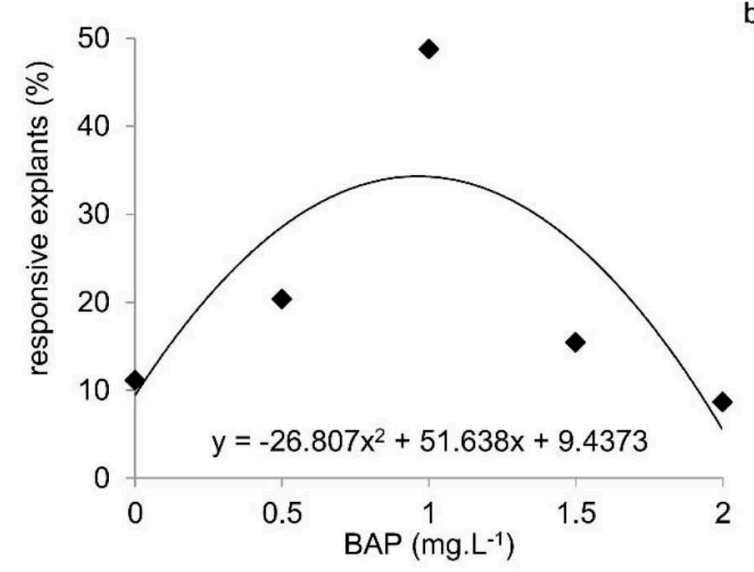

c)
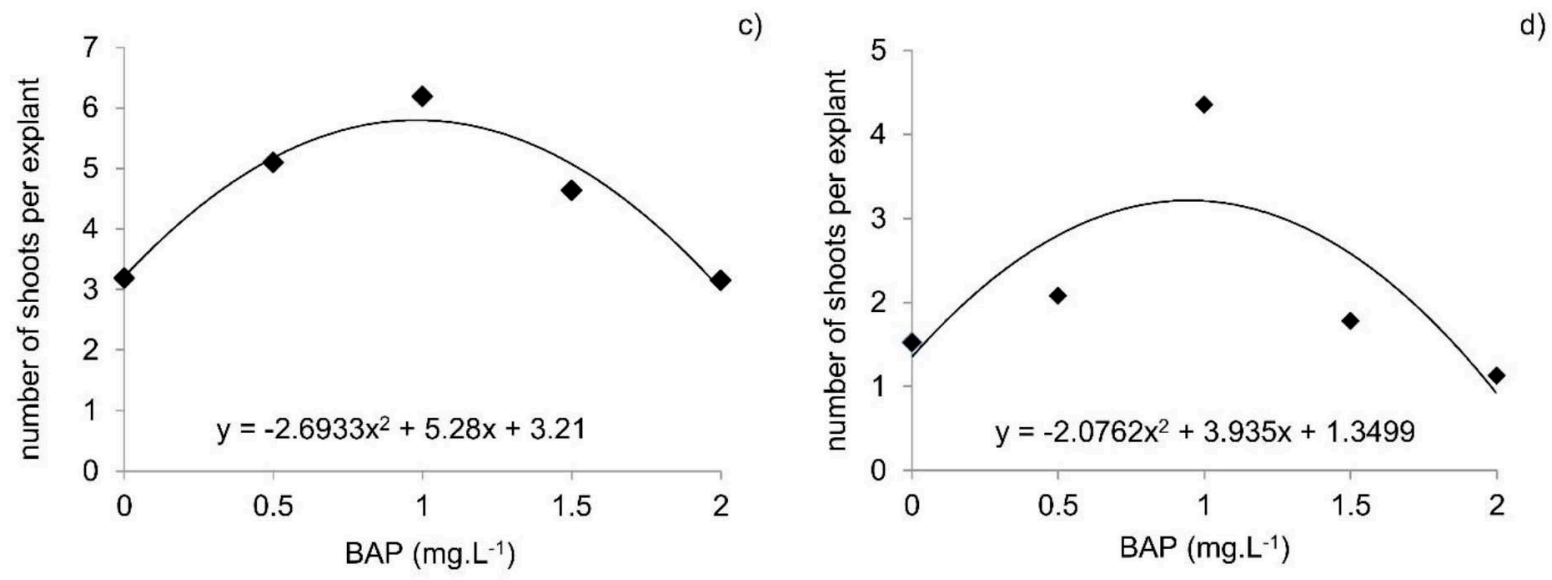

b)

Figure 1. In vitro organogenesis of epicotyl and internodal-derived explants from Fremont, Thomas and Nules mandarin cultivars under the influence of the different concentration of BAP a-b) Mean of percentage of responsive explants derived from epicotyl (a) and internodal (b) segments for Fremont, Thomas, and Nules. c-d) Mean of number of shoots per explants derived from epicotyl (c) and internodal (d) segments for Fremont, Thomas, and Nules.

Table 2. Fremont, Thomas, and Nules mandarin genetic transformation experiments with gene constructs harboring the attacin A gene associated with phloem-specific promoters.

\begin{tabular}{ccccc}
\hline \multirow{2}{*}{ genotype } & gene construct & $\begin{array}{c}\text { no. PCR-positive } \\
\text { plants/ } \\
\text { total explants }\end{array}$ & $\begin{array}{c}\text { genetic transformation ef- } \\
\text { ficiency }(\%)^{\mathrm{a}}\end{array}$ & \begin{tabular}{c} 
no. Southern blot + plants \\
\multirow{2}{*}{ Fremont }
\end{tabular} \\
& pCAtPP2/attA & $3 / 1378$ & 0.22 & 3 \\
& pCAtSuc2/attA & $8 / 1874$ & 0.43 & 8 \\
\multirow{2}{*}{ Thomas } & pCAtPP2/attA & $10 / 1743$ & 0.57 & 12 \\
& pCAtSuc2/attA & $12 / 1297$ & 0.93 & 1 \\
\hline
\end{tabular}

a PCR-positive plants (x100) / total explants 


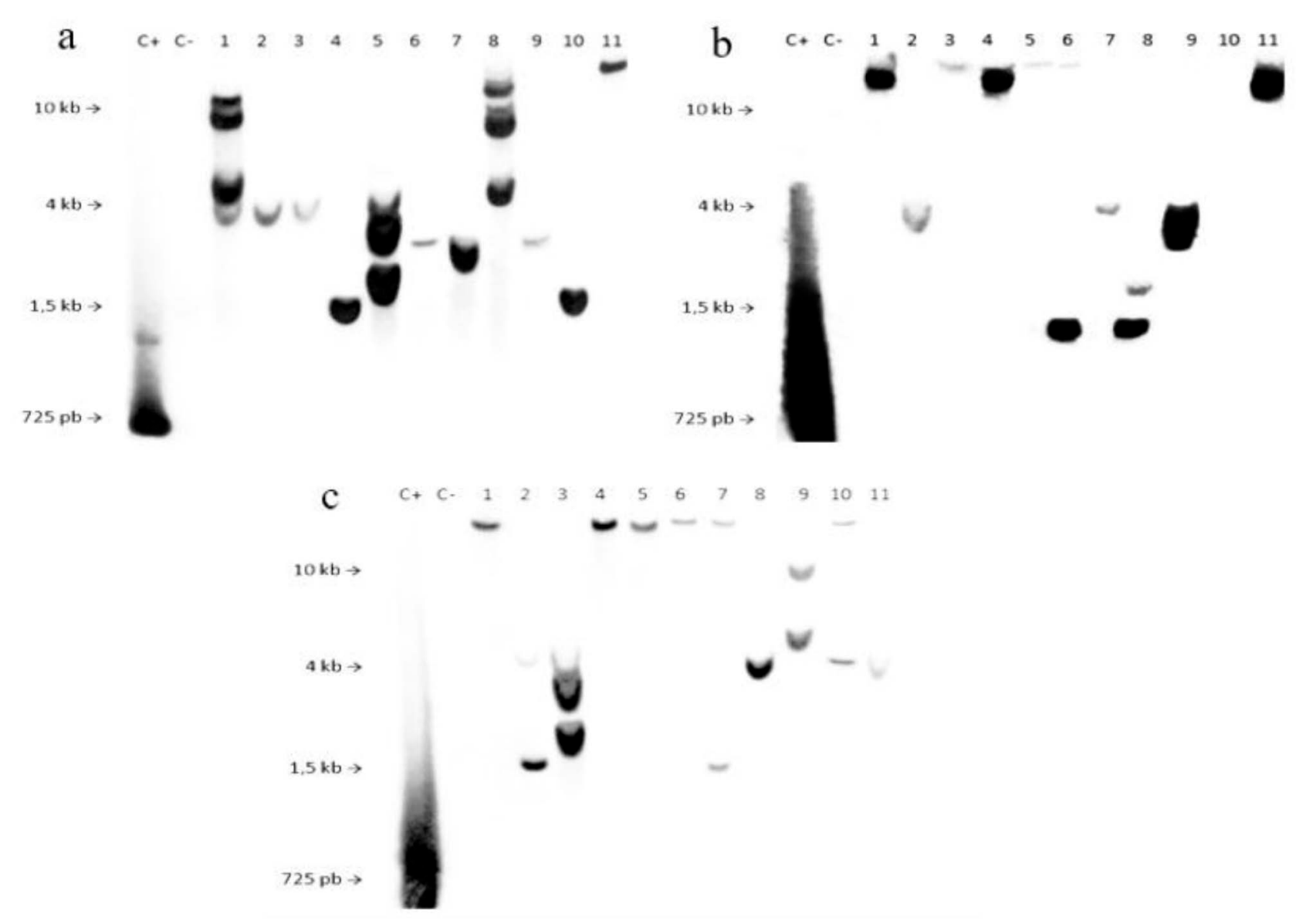

Figure 2. Southern blot analyses of transgenic plants of mandarin cultivars Thomas, Fremont and Nules transformed with pCAtPP2/attA (a) or pCAtSuc2/attA (b-c) gene constructs. a) Plants of cv. Fremont (events 1-3), Thomas (events 4-10) and Nules (event 11). Events 2, 3, 4, 6, 7, 9, 10 and 11 have one insertion. Events 1, 5 and 8 have more than three insertions. b) Plants of cv. Fremont (events 1-8), Thomas (event 9) and Nules (events 10-11). Events 1, 2, 3, 4, 5, 7, 9 and 11 have one insertion. Events 6 and 8 have two insertions. Event 10 not transformed. c) Plants of cv. Thomas (events 1-11). Events 1, 4, 5, 6, 8 and 11 have one insertion. Events 2, 7, 9 and 10 have two insertions. Event 3 has three insertions. $\mathrm{C}+$ : positive control (725 bp fragment of attA gene). C-: negative control (DNA from non-transgenic plant). Total DNA from transgenic and non-transgenic plants was digested with BamHI (pCAtSuc2/attA) or HimdIII (pCAtPP2/ attA) and hybridized with a probe of the attA gene (150 ng). 


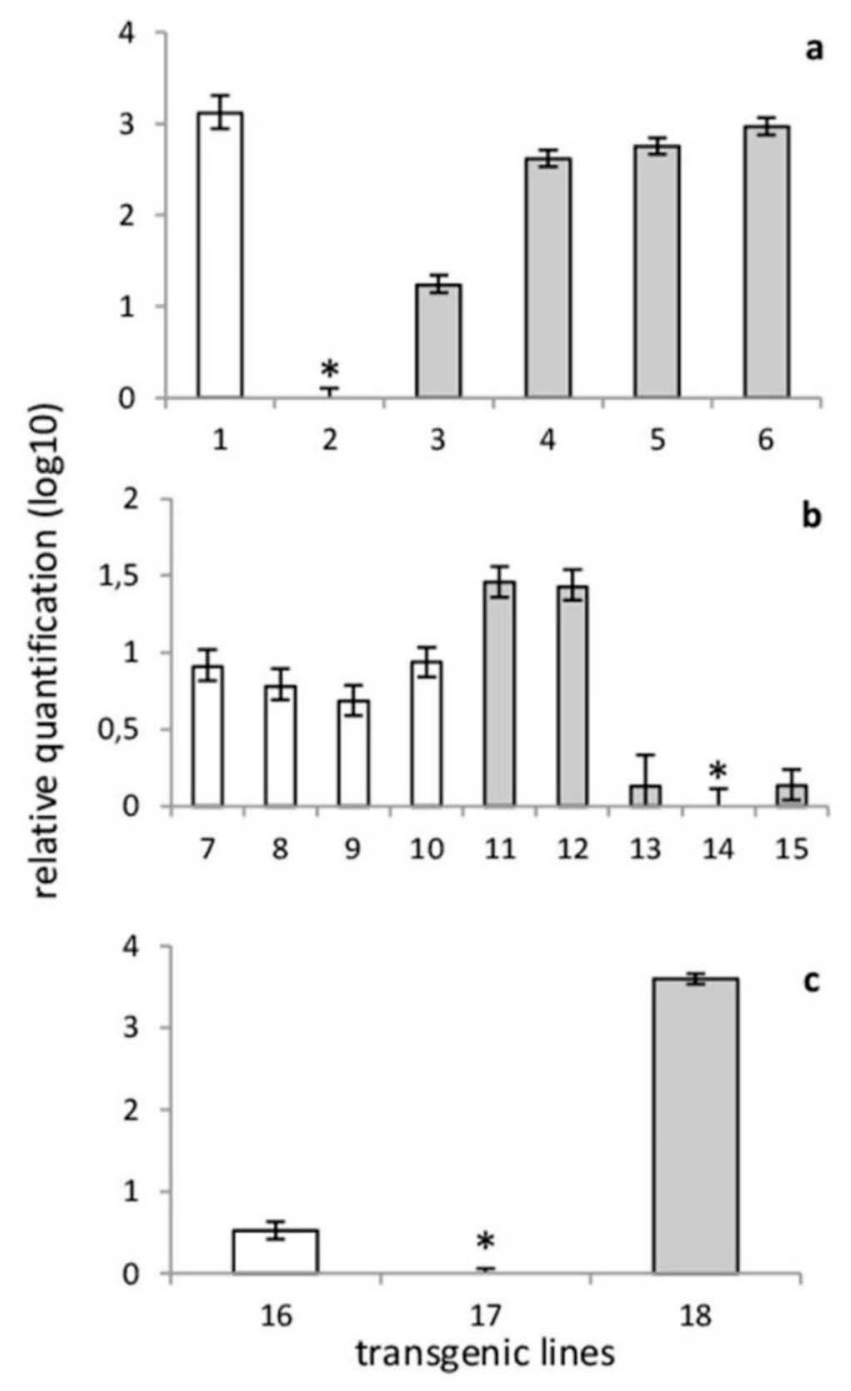

\section{$\square$ pCAtPP2/attA $\square \quad$ pCAtSUC2/attA}

Figure 3. Relative quantification of the attA gene expression in transgenic plants of Thomas, Fremont, and Nules mandarin cultivars. a) Transgenic lines of Fremont cv. containing pCAtPP2/attA (bars 1 - 2) or pCAtSuc2/ attA (bars 3 - 6) gene constructs. b) Transgenic lines of Thomas cv. containing pCAtPP2/attA (bars 7 - 10) or pCAtSuc2/attA (bars 11 - 15) gene constructs. c) Transgenic lines of Nules cv. containing pCAtPP2/ attA (bar 16) or pCAtSuc2/attA (bars 17-18) gene constructs. Relative expression of the target gene was normalized with the ubiquitin (UBQ) gene and calculated in relation to the transgenic line that presented the lowest $\Delta \mathrm{Ct}$ value $(*)$.

\section{Conclusion}

This study evaluated and confirmed an efficient in vitro organogenesis and plant regeneration protocol for three different mandarin cultivars. Epicotyl-derived explants in culture medium supplemented with BAP (1 $\mathrm{mg} \mathrm{L}^{-1}$ ) led to high regeneration frequency. The in vitro organogenesis protocol of mandarin cultivars allowed the production of transgenic plants from Fremont, Thomas, and Nules cultivars expressing the attA gene under the control of phloem-specific promoters.

\section{Acknowledgments}

The authors acknowledge Bebedouro Citrus Experiment Station (Estação Experimental de Citricultura de Bebedouro) for providing the plant material; São Paulo Research Foundation (Fundação de Amparo à Pesquisa do Estado de São Paulo - FAPESP) for granting fellowship to LS and ECRT and for granting financial support to this project; National Council for Scientific and Technological Development (Conselho Nacional de Desenvolvimento Científico e Tecnológico - CNPq) for granting research fellowship to BMJM and FAAMF. The authors thank Maurel Behling and Sônia Maria De Stefano Piedade for support and advice on statistical analysis; Liliane Cristina Liborio Stipp and Renata Beatriz Cruz for technical support. 


\section{References}

ALMEIDA, W.A.B.; MOURÃO FILHO, F.A.A.; MENDES, B.M.J.; RODRIGUEZ, A.P.M. In vitro organogenesis optimization and plantlet regeneration in Citrus sinensis and C. limonia. Scientia Agricola, Piracicaba, v.59, n.1, p.35-40, 2002.

AZEVEDO, F.A.; MOURÃO FILHO, F.A.A.; MENDES, B.M.J.; ALMEIDA, W.A.B.; SCHINOR, E.H.; PIO, R.; BARBOSA, J.M.; GUIDETTI-GONZALEZ, S.; CARRER, H.; LAM, E. Genetic transformation of rangpur lime (Citrus limonia Osbeck) with the $b O$ (bacterioopsin) gene and its initial evaluation for Phytophthora nicotianae resistance. Plant Molecular Biology Reporter, Düsseldorf, v.24, n.2, p.185-196, 2006.

BACHCHU, M.A.A.; JIN, S.B.; PARK, J.W.; SUN, H.J.; YUN, S.H.; LEE, H.Y.; LEE, D.S.; HONG, Q.C.; KIM, Y.W.; RIU, K.Z.; KIM, J.H. Agrobacterium-mediated transformation using embryogenic calli in satsuma mandarin (Citrus unshiu Marc.) cv. Miyagawa Wase. Horticulture, Environment, and Biotechnology, Seoul, v.52, n.2, p.170-175, 2011.

BARBOSA-MENDES, J.M.; MOURÃO FILHO; F.A.A.; BERGAMIN FILHO; A.; HARAKAVA, R.; BEER; S.V.; MENDES, B.M.J. Genetic transformation of Citrus sinensis cv. Hamlin with hrpN gene from Erwinia amylovora and evaluation of the transgenic lines for resistance to citrus canker. Scientia Horticulturae, Amsterdam, v.122, n.1, p.109-115, 2009.

BASSAN, M.M.; MOURÃO FILHO, F.A.A.; MIYATA, L.Y.; MENDES, B.M.J. In vitro organogenesis from internodal segments of adult sweet orange plants. Pesquisa Agropecuária Brasileira, Brasília, DF, v.46, n.6, p.672-674, 2011.

BOAVA, L.P.; CRISTOFANI-YALY, M.; MAFRA, V.S.; KUBO, K.; KISHI, L.T.; TAKITA, M.A.; RIBEIROALVES, M.; MACHADO, M. Global gene expression of Poncirus trifoliata, Citrus sunki and their hybrids under infection of Phytophthora parasitica. BMC Genomics, London, v.12, n.1., p.39, 2011.

BORDÓN, Y.; GUARDIOLA, J.L.; GARCÍA-LUIS, A. Genotype affects the morphogenic response in vitro of epicotyl segments of Citrus rootstocks. Annals of Botany, Oxford, v.86, n.1, p.159-166, 2000.
BOSCARIOL, R.L.; MONTEIRO, M.; TAKAHASHI, G.K.; CHABREGAS, S.M.; VIEIRA, M.L.C.; VIEIRA, L.G.E.; PEREIRA, L.F.P.; MOURÃO FILHO, F.A.A.; CARDOSO, S.C.; CHRISTIANO, R.S.C.; BERGAMIN FILHO, A.; BARBOSA, J.M.; AZEVEDO, F.A.; MENDES, B.M.J. Attacin A gene from Tricloplusia $n i$ reduces susceptibility to Xanthomonas axonopodis pv. citri in transgenic Citrus sinensis cv. Hamlin. Journal of the American Society for Horticultural Science, Geneva, v.131, n.4, p.530-536, 2006.

BOVÉ, J.M. Huanglongbing: a destrutive, newlyemerging, century-old disease of citrus. Journal of Plant Pathology, Dordrecht, v. 88, n.1, p.7-37, 2006.

CARDOSO, S.C.; BARBOSA-MENDES, J.M.; BOSCARIOL-CAMARGO, R.L.; CHRISTIANO, R.S.C.; BERGAMIN FILHO, A.; VIEIRA, M.L.C.; MENDES, B.M.J.; MOURÃO FILHO, F.A.A. Transgenic sweet orange (Citrus sinensis L. Osbeck) expressing the attacin A gene for resistance to Xanthomonas citri subsp. citri. Plant Molecular Biology Report, Düsseldorf, v.28, n.2, p.185-192, 2010.

CERVERA, M.; NAVARRO, A.; NAVARRO, L.; PEÑA, L. Production of transgenic adult plants from Clementine mandarin by enhancing cell competence for transformation and regeneration. Tree Physiology, Victoria, v.28, n.1, p.55-66, 2008.

CostA, M.G.C.; OTONI, W.C.; MOORE, G.A. An evaluation of factors affecting the efficiency of Agrobacterium-mediated transformation of Citrus paradisi (Macf.) and production of transgenic plants containing carotenoid biosynthetic genes. Plant Cell Reports, Berlin, v.21, n.4, p.365-373, 2002.

DONMEZ, D.; SIMSEK, O.; IZGU, T.; KACAR, Y.A.; MENDI, Y.Y. Genetic transformation in citrus. The Scientific World Journal, London, v.2013, p.8, 2013. Article ID 491207. http://dx.doi. org $/ 10.1155 / 2013 / 491207$

DOYLE, J.J.; DOYLE, J.L. Isolation of plant DNA from fresh tissue. Focus, Rockville, v. 12, p.13-15, 1990.

DUTT, M.; ERPEN, L.; GROSSER, J.W. Genetic transformation of the 'W Murcott' tangor: comparison between different techniques. Scientia Horticulturae, New York, v.242, p.90-94, 2018.

DUTT, M.; GROSSER, J.W. Evaluation of parameters affecting Agrobacterium-mediated transformation of citrus. Plant Cell, Tissue and Organ Culture, Dordrecht, v.98, n.3, p.331-340, 2009. 
GARCÍA-LUIS, A.; MOLINA, R.V.; VARONA, V.; CASTELLO, S.; GUARDIOLA, J.L. The influence of explant orientation and contact with the medium on the pathway of shoot regeneration in vitro in epicotyl cuttings of Troyer citrange. Plant Cell, Tissue and Organ Culture, Dordrecht, v.85, n.2, p.137-144, 2006.

GHORBEL, R.; DOMÍNGUEZ, A.; NAVARRO, L.; PEÑA, L. High efficiency genetic transformation of sour orange (Citrus aurantium) and production of transgenic trees containing the coat protein gene of citrus tristeza virus. Tree Physiology, Victoria, v.20, n.17, p.1183-1189, 2000 .

GUTIÉRREZ-E, M.A.; LUTH, D.; MOORE, G.A. Factors affecting Agrobacterium mediated transformation in Citrus and production of sour orange (Citrus aurantium L.) plants expressing the coat protein gene of citrus tristeza virus. Plant Cell Reports, New York, v. 16, n.11, p.745753, 1997.

KHAN, E.H.; FU, X.Z.; WANG, J.; FAN, Q.J.; HUANG, X.S.; ZHANG, G.N.; SHI, J.; LIU, J.H. Regeneration and characterization of plants derived from leaf in vitro culture of two sweet orange (Citrus sinensis (L.) Osbeck) cultivars. Scientia Horticulturae, New York, v.120, n.1, p.70-76, 2009.

KHAWALE，R.N.; SINGH，S.K.; GARG，G.; BARANWAL, V.K.; AJIRLO, S.A. Agrobacteriummediated genetic transformation of Nagpur mandarin (Citrus reticulata Blanco). Current Science, New York, v.91, n.12, p.1700-1705, 2006.

KOBAYASHI, A.; UCHIMIYA, H. Expression and integration of a foreign gene in orange (Citrus sinensis Osb.) protoplasts by direct DNA transfer. Japanese Journal of Genetics, Mishima, v.64, n.2, p.91-97, 1989.

MAGGON, R.; SINGH, B.D. Promotion of adventitious bud regeneration by ABA in combination with BAP in epicotyl and hypocotyl explants of sweet orange (Citrus sinensis L. Osbeck). Scientia Horticulturae, New York, v.63, n.1, p.123-128, 1995.

MARQUES, N.T.; NOLASCO, G.B.; LEITÃO, J.P. Factors affecting in vitro adventitious shoot formation on internode explants of Citrus aurantium L. cv. Brazilian. Scientia Horticulturae, New York, v.129, n.2, p.176182, 2011.
MIYATA, L.M.; HARAKAVA, R.; STIPP, L.C.L.; MENDES, B.M.J.; APPEZZATO-DA-GLÓRIA, B.; MOURÃO FILHO, F.A.A. GUS expression in sweet oranges (Citrus sinensis L. Osbeck) driven by three different phloem-specific promoters. Plant Cell Reports, New York, v.31, n.11, p.2005-2013, 2012.

MOREIRA-DIAS, J.M.; MOLINA, R.V.; GUARDIOLA, J.L.; GARCÍA-LUIS, A. Day length and photon flux density influence the growth regulator effects on morphogenesis in epicotyl segments of Troyer citrange. Scientia Horticulturae, Amsterdam, v.87, n.4, p.275290, 2001.

MURASHIGE, T.; SKOOG, F. A revised medium for rapid growth and bioassay with tobacco tissue culture. Physiologia Plantarum, Copenhagen, v.15, n.1, p.473497, 1962.

MURASHIGE, T.; TUCKER, D.P.H. Growth factor requirements of citrus tissue culture. In: CITRUS SYMPOSIUM, 1., 1969, Riverside. Proceedings [...]. Riverside: University of California, 1969. p.1155-1161.

NWE, Y.Y.; MYINT, K.T.; MOCHIZUKI, Y.; VAZIRZANJANI, M.; OKAYASU, K.; SUZUKI, S.; OGIWARA, I. In vitro regeneration through direct shoot organogenesis in Honey Orange (Citrus tangerina). Plant Biotechnology, Tokyo, v.31, n.4, p.341-344, 2014.

OLIVEIRA, M.L.P.; COSTA, M.G.C.; SILVA, C.V.; OTONI, W.C. Growth regulators, culture media and antibiotics in the in vitro shoot regeneration from mature tissue of citrus cultivars. Pesquisa Agropecuária Brasileira, Brasília, DF, v.45, n.7, p.654-660, 2010.

PFAFFL, M.W.; HORGAN, G.W.; DEMPFLE, L. Relative expression software tool (REST) for group-wise comparison and statistical analysis of relative expression results in real-time PCR. Nucleic Acids Research, Oxford, v.30, n.9, p.e36, 2002.

PIO, R.M.;AZEVEDO, F.A.; NEGRI, J.D.; FIGUEIREDO, J.O.; CASTRO, J.L. Características da variedade Fremont quando comparadas com as das tangerinas 'Ponkan' e 'Clementina Nules'. Revista Brasileira de Fruticultura, Jaboticabal, v.28, n.2, p.222-226, 2006.

RAMAKERS, C.; RUIJTER, J.M.; DEPREZ, R.H.; MOORMAN, A.F. Assumption-free analysis of quantitative real-time polymerase chain reaction (PCR) data. Neuroscience Letters, New Haven, v.339, n.1, p.62-66, 2003. 
RODRÍGUEZ, A.; CERVERA, M.; PERIS, J.E.; PEÑA, $\mathrm{L}$. The same treatment for transgenic shoot regeneration elicits the opposite effect in mature explants from two closely related sweet orange (Citrus sinensis (L.) Osb.) genotypes. Plant Cell, Tissue and Organ Culture, Dordrecht, v.93, n.1, p.97-106, 2008.

SILVA, R.P.; SOUZA, E.S.; REBOUÇAS, F.S.; ALMEIDA, W.A.B. Otimização de protocolos para regeneração de plantas in vitro de tangerina 'Cleópatra' (Citrus reshni Hort. ex Tan.). Revista Brasileira de Fruticultura, Jaboticabal, v.27, n.3, p.484-487, 2005.

SORIANO, L.; TAVANO, E.C.R.; BEHLING, A.; MOURÃO FILHO, F.A.A.; MENDES, B.M.J. In vitro organogenesis of rangpur lime. Revista Brasileira de Fruticultura, Jaboticabal, v.34, n.2, p.349-355, 2012.

TAVANO, E.C.R.; STIPP, L.C.L.; MUNIZ, F.R.; MOURÃO FILHO, F.A.A.; MENDES, B.M.J. In vitro organogenesis of Citrus volkameriana and Citrus aurantium. Biologia Plantarum, Dordrecht, v.53, n.2, p.395-399, 2009.
TAVANO, E.C.R.; VIEIRA, M.L.C.; MOURÃO FILHO, F.A.A.; HARAKAVA, R.; MENDES, B.M.J. Genetic transformation of Citrus sinensis 'Hamlin' with attacin A driven by a phloem tissue-specific promoter for resistance to Candidatus Liberibacter spp. Acta Horticulturae, Leuven, v.1065, n.1, p.695-702, 2015.

YANG, L.; HU, W.; XIE, Y.; LI, Y.; DENG, Z. Factors affecting Agrobacterium-mediated transformation efficiency of kumquat seedling internodal stem segments. Scientia Horticulturae, New York, v.209, n.1, p.105-112, 2016.

ZOU, X.; LI, D.; LUO, X.; LUO, K.; PEI, Y. An improved procedure for Agrobacterium-mediated transformation of trifoliate orange (Poncirus trifoliate L. Raf.) via indirect organogenesis. In Vitro Cellular and Developmental Biology-Plant, Gaithersburg, v.44, n.3, p.169-177, 2008. 